\title{
Applicability of Euphorbia milii var splendens latex in the control of Biomphalaria
}

\section{tenagophila}

\author{
Aplicabilidade do látex de Euphorbia milii var splendens no controle de Biomphalaria tenagophila \\ Aplicabilidad del látex de Euphorbia milii var splendens en el control de Biomphalaria tenagophila
}

\author{
Matheus Diniz Gonçalves Coêlho \\ ORCID: https://orcid.org/0000-0002-7903-1429 \\ FUNVIC University Center, Brazil \\ E-mail: prof.matheuscoelho.pinda@unifunvic.edu.br \\ Cristiane de Carvalho Esteves \\ ORCID: https://orcid.org/0000-0002-5437-963X \\ FUNVIC University Center, Brazil \\ E-mail: cristianecarvalhoesteves@gmail.com \\ Carolina Aparecida Bastos \\ ORCID: https://orcid.org/0000-0002-2485-6685 \\ FUNVIC University Center, Brazil \\ E-mail: carolinabastos48@hotmail.com \\ Aline Fátima de Melo \\ ORCID: https://orcid.org/0000-0002-2523-8045 \\ FUNVIC University Center, Brazil \\ E-mail: alinemelo166@outlook.com \\ Lucas Tobias Rodrigues Maciel \\ ORCID: https://orcid.org/0000-0002-2906-6674 \\ FUNVIC University Center, Brazil \\ E-mail: 1trmaciel@gmail.com
}

\begin{abstract}
The present work aimed to evaluate in vitro the molluscicidal activity and latex toxicity of Euphorbia milii var. splendens (Bojer ex Hook) Ursch \& Leandri for the control of mollusks of the species Biomphalaria tenagophila. Specimens of E. milii var. splendens cultivated in the rural region of Pindamonhangaba were selected, from which latex was obtained by the transverse incision of the aerial parts. For the molluscicide test, adult mollusks of the species B. tenagophila were separated into groups of 10 and submitted to latex immersion at concentrations of 2.5 ppm, $1.25 \mathrm{ppm}, 0.625 \mathrm{ppm}$, and $0.3125 \mathrm{ppm}$ for 24 hours. In parallel, the toxicity of latex at a concentration of 0.3125 ppm was determined by testing with Artemia salina (mortality assessment) and using the Allium cepa test (determination of growth inhibition, amount, and weight of roots). It was observed an important molluscicidal activity of $E$. milii var. splendens latex at the various concentrations evaluated. In addition, it was also possible to observe moderate toxicity against $A$. salina nauplii and in the toxicity test with $A$. cepa. This demonstrates the potential of using latex from E. milii var. splendens to control populations of $B$. tenagophila species, not only for the observed molluscicidal activity but also for the moderate mortality of A. salina nauplii, whereas in the A. cepa test no change was observed in the parameters evaluated in relation to the control group, demonstrating safety for use in the environment.
\end{abstract}

Keywords: Biomphalaria; Toxicicity; Euphorbia milii; Euphorbiaceae.

\section{Resumo}

O presente trabalho teve como objetivo avaliar in vitro a atividade moluscicida e a toxicidade do látex de Euphorbia milii var. splendens (Bojer ex Hook) Ursch \& Leandri para o controle de moluscos da espécie Biomphalaria tenagophila. Foram selecionados espécimes de E. milii cultivados na região rural de Pindamonhangaba, dos quais o látex foi obtido por incisão transversal da parte aérea. Para o teste do moluscicida, moluscos adultos da espécie $B$. tenagophila foram separados em grupos de 10 e submetidos à imersão em látex nas concentrações de 2,5 ppm, 1,25 ppm, 0,625 ppm e 0,3125 ppm por 24 horas. Paralelamente, a toxicidade do látex na concentração de 0,3125 ppm foi determinada com Artemia salina (avaliação da mortalidade) e usando o teste Allium cepa (determinação da inibição do crescimento, quantidade e peso das raízes). Foi observada importante atividade moluscicida de látex de $E$. miliii nas várias concentrações avaliadas. Além disso, também foi possível observar toxicidade moderada contra náuplios de $A$. salina e no teste de toxicidade com A. cepa. Isso demonstra o potencial do uso de látex de E. milii var. splendens para controle de populações de espécies de B. tenagophila, não só pela atividade moluscicida observada, mas também pela 
mortalidade moderada de náuplios de A. salina, enquanto no teste de A. cepa nenhuma alteração foi observada nos parâmetros avaliados em relação ao grupo controle, demonstrando segurança para uso no meio ambiente.

Palavras-chave: Biomphalaria; Toxicidade; Euphorbia milii; Euphorbiaceae.

\section{Resumen}

El presente trabajo tuvo como objetivo evaluar in vitro la actividad molusquicida y la toxicidad del látex de Euphorbia milii var. splendens (Bojer ex Hook) Ursch \& Leandri para el control de moluscos de la especie Biomphalaria tenagophila. Se seleccionaron ejemplares de E. milii cultivados en la región rural de Pindamonhangaba, de los cuales se obtuvo el látex por incisión transversal de la parte aérea. Para la prueba de molusquicidas, los moluscos adultos de la especie $B$. tenagophila se separaron en grupos de 10 y se sumergieron en látex a concentraciones de 2,5 ppm, 1,25 ppm, 0,625 ppm y 0,3125 ppm durante 24 horas. Paralelamente, se determinó la toxicidad del látex a una concentración de 0,3125 ppm mediante la prueba con Artemia salina (evaluación de la mortalidad) y la prueba de Allium cepa (determinación de la inhibición del crecimiento, cantidad de raíces y peso). Se observó una importante actividad molusquicida del látex de E. milii a las diversas concentraciones evaluadas. Además, también se pudo observar una toxicidad moderada frente a A. salina y en la prueba de toxicidad con $A$. cepa. Esto demuestra el potencial del uso de látex de E. milii para controlar las poblaciones de especies de B. tenagophila, no solo debido a la actividad molusquicida observada, sino también a la mortalidad moderada de $A$. salina, mientras que en la prueba de $A$. серa no se observaron cambios. observado en los parámetros evaluados en relación al grupo de control, demostrando seguridad para su uso en el medio ambiente.

Palabras clave: Biomphalaria; Toxicidad; Euphorbia milii; Euphorbiaceae.

\section{Introduction}

Schistosomiasis is a disease whose etiological agents are trematode species of the genus Schistosoma Weiland, 1858 (Santos et al., 2020; Martins et al., 2021). About 200 million people are infected with at least one of the top five species that parasitize humans: Schistosoma haematobium (Bilharz, 1852), Schistosoma mansoni (Sambon, 1907), Schistosoma japonicum (Katsurada, 1904), Schistosoma intercalatum (Fisher, 1934) and Schistosoma mekongi (Voge, Brikener \& Bruce, 1978). After malaria, schistosomiasis is the parasitic disease with the highest morbidity in the world, with a high prevalence in Africa, Latin America, the Middle East, Asia, and the Caribbean (Fenwick \& Jourdan, 2016; Toor et al., 2018; Gomes et al., 2019; Holanda et al., 2020).

The endemic was introduced in Brazil with the African slave trade and, certainly, other species of Schistosoma would have been installed in that country if there were adequate intermediate hosts. Furthermore, the areas of transmission of the parasitosis show a close association with the spatial distribution of Biomphalaria glabrata (Say, 1818), B. tenagophila (Orbigny, 1835), and B. straminea (Dunker, 1848), the only three species of planorbid mollusks that, under natural conditions, transmit S. mansoni in our environment (Silveira, Marçal \& Machado, 1997; Lopes et al., 2017).

Between 2008 and 2016, the surveillance of schistosomiasis worked with 12.411 .898 people, of which 9.140.139 were examined, 425.231 were positive and 363.857 received treatment. During this period, 2.275 hospitalizations for schistosomiasis and 4.473 deaths were recorded. Currently, there are outbreaks of schistosomiasis in several municipalities in the valleys of the Ribeira de Iguapé and Paraíba do Sul rivers, the Litoral Paulista, and the metropolitan regions of Campinas and Greater São Paulo (Brasil, 2018).

Therefore, schistosomiasis deserves attention, whether because of the number of cases in the world, more than 200 million or because of the morbidity it causes. However, the Brazilian Society of Tropical Medicine points out that in Brazil, fortunately, we only have schistosomiasis mansoni, which affects more than 70 million people worldwide (SBMT, 2019).

Schistosomiasis mansoni has in its biological cycle the involvement of mollusks of the genus Biomphalaria, which are the only intermediate hosts, and has man as the definitive host. This disease is popularly known as "mollusks disease" and/or "water belly", which courses with an acute or chronic condition, often with few symptoms or asymptomatic, but can also manifest in more severe forms, with an outcome of the death of the host (Rocha et al., 2016; Everton et al., 2020).

Schistosomiasis mansoni has in its biological cycle the involvement of mollusks of the genus Biomphalaria, which are 
only intermediate hosts, and has man as the definitive host. This disease is popularly known as "mollusks disease" and/or "water belly", which courses with an acute or chronic condition, often with few symptoms or asymptomatic, but can also manifest in more severe forms, with an outcome of the death of the host (Rocha et al., 2016).

The application of natural molluscicides products in the focus of disease transmission has received special attention from researchers. Although the synthetic products used are effective in eliminating the molluscum from the focus of infection, they have a biocidal action on non-target organisms of flora and fauna, in addition to expressing levels of genotoxicity and carcinogenic effect, so plant-derived products are an alternative to the effects undesirables found in the synthetic molluscicides studied so far. Among the bioactive herbal medicines for S. mansoni host mollusks, E. milii (Syn. splendens) var. hislopii latex is the main product to be used in campaigns for the large-scale control of schistosomiasis (Michelson, 1988; Martins et al., 2021).

The species that has great epidemiological importance in the transmission of $S$. mansoni in the states of the South and Southeast regions are B. tenagophila. The species is responsible for most of the autochthonous cases of schistosomiasis in the state of São Paulo and the outbreaks of the disease in the state of Santa Catarina. It was notified in 562 municipalities in 10 brazilian states (Bahia, Espírito Santo, Goiás, Mato Grosso do Sul, Minas Gerais, Paraná, Rio de Janeiro, Rio Grande do Sul, Santa Catarina and São Paulo) in addition to the Federal District. The species is found in a coastal strip, almost continuously from the south of the state of Bahia to the state of Rio Grande do Sul (Brasil, 2014).

Thus, this study aimed to evaluate in vitro the molluscicidal activity and latex toxicity of E. milii var. splendens (Bojer ex Hook) Ursch \& Leandri, popularly known as "Crown of Christ", for the control of mollusks of the species B. tenagophila.

\section{Methodology}

For the experimental design, specimens of E. milii var. splendens cultivated in the Piracuama district, rural region of the municipality of Pindamonhangaba, from which the latex was obtained through a transversal incision of the aerial parts.

The vegetable drug obtained was transported in an amber bottle with a lid to the LAPAM - Parasitology and Malacology Laboratory at UNIFUNVIC. For the molluscicide test, adult mollusks of the species B. tenagophila were selected, with a diameter between 0.8 and $1.2 \mathrm{~cm}$, all from the LAPAM mollusk breeding, which were separated into groups of 10, then triplicated, and submitted to immersion in latex at concentrations of $2.5 \mathrm{ppm}, 1.25 \mathrm{ppm}, 0.625 \mathrm{ppm}$, and $0.3125 \mathrm{ppm}$, for 24 hours. After this period, the mollusks were placed in dechlorinated water and observed for mortality verification. To determine the toxicity, the test with Allium cepa was used, according to the methodology used by Pinto et al. (2017), using 20 commercially obtained onion bulbs. These were washed, had their dead roots removed with the aid of scissors, and their weight determined with the aid of analytical scales available at the LAFAPLAM - Pharmacognosy and Medicinal Plants Laboratory of UNIFUNVIC. Then, the bulbs were exposed, by contacting the root region, to determined dilutions of the latex in conditioning water and pure conditioning water, which was used as a negative control. For the latex dilution and the control group, ten bulbs were used, being evaluated the dilution of $0.3125 \mathrm{ppm}$ (which was the lowest concentration tested in the present work). The solution was then placed in goblets, which were filled to the brim. Each bulb was conditioned with the aid of wooden sticks, which were gently fixed to the bulb, in order to allow adequate oxygenation of the root region.

The bulbs remained for 96 hours in contact with the solutions, at room temperature, and protected from light, with the root area immersed. At the end of 96 hours, toxicity was evaluated by determining root growth inhibition, number of roots, immediate wet weight of roots, the immediate weight of bulbs, and length of roots.

In parallel, the toxicity of latex was determined by testing with Artemia salina in duplicate. The methodology used by Coêlho et al. (2018), was followed. To verify the applicability of the latex in the environment, the minimum dilution ( 0.3125 
ppm) that had a significant molluscicidal effect was submitted to the toxicity test. The commercially obtained microcrustacean cysts were subjected to a solution containing saline water $(2 \mathrm{~g} / \mathrm{L}$ of sea salt) for 48 hours. The nauplii obtained were placed in test tubes (10 per tube) containing E. milii latex at a concentration of $0.3125 \mathrm{ppm}$, in a volume of $5 \mathrm{~mL}$ of saline water $(2 \mathrm{~g} / \mathrm{L}$ of sea salt). The experiment was carried out in duplicate and the determination of the ratio of live dead nauplii was carried out after 24 hours. As a control group, the nauplii obtained were placed in test tubes (10 per tube) containing saline water $(2 \mathrm{~g} / \mathrm{L}$ of sea salt).

To investigate differences in the results of adult mollusks mortality, in the test variables with A. cepa and the toxicity test with A. salina, the Kruskal-Wallis test was used, followed by the Student-Newman-Keuls test, and the significant differences were considered between the means with $\mathrm{p}<0.05$, using the Bioestat 5.0 software as a tool.

\section{Results}

It was observed that the concentrations evaluated, namely: $2.5 \mathrm{ppm}, 1.25 \mathrm{ppm}, 0.625 \mathrm{ppm}$, and $0.3125 \mathrm{ppm}$, the latex of E. milii induced $100 \%$ mortality of B. tenagophila mollusks. As for the toxicity of latex at 0.3125 ppm dilution (EM group 0.3125), in the test with A. salina there was an average coefficient of $56.7 \%$ of mortality of nauplii, this value being significantly higher $(\mathrm{p}<0.05)$ to the mean mortality coefficient observed in the control group, which was $5 \%$, as shown in Figure 1.

Figure 1. Mortality of Artemia salina nauplii after exposure to E. milii latex at 0.3125 ppm dilution.

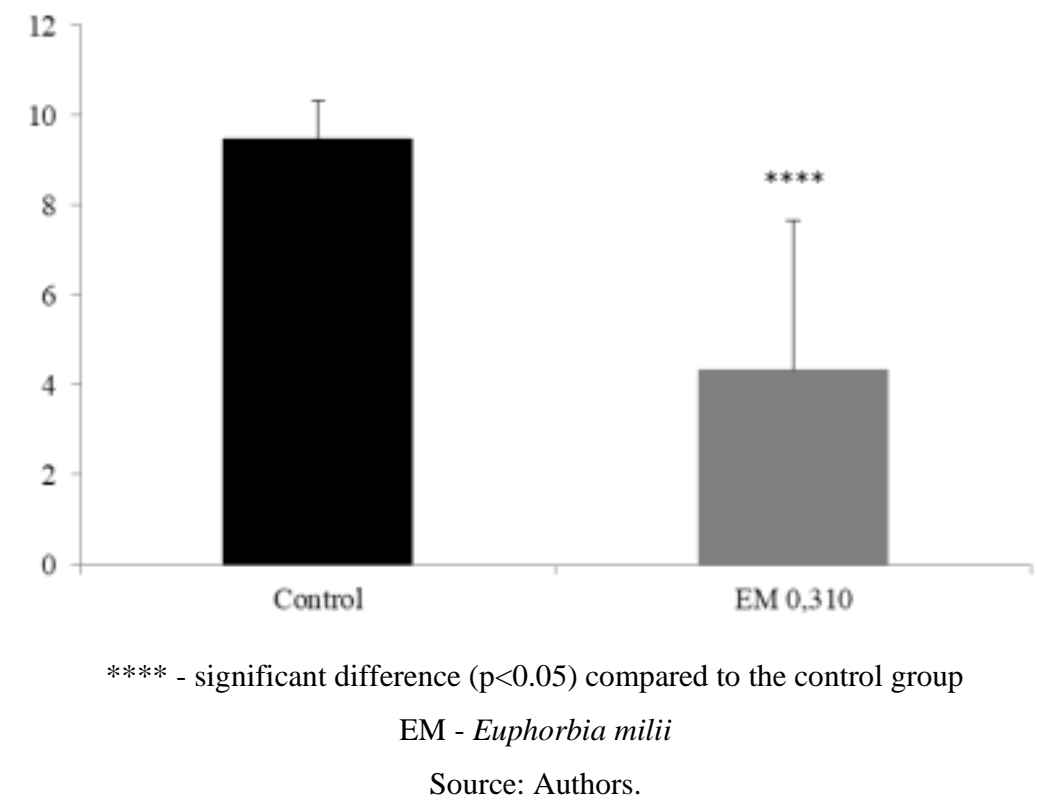

Finally, in the test with A. серa to determine toxicity, there were no significant differences in the criteria: number of roots, length of roots, and weight of roots, between the control group and the group treated with E. milii latex, in the concentration of $0.3125 \mathrm{ppm}$, according to Table 1 . 
Table 1. Results of the toxicity test with Allium cepa of Euphorbia milii latex at 0.3125 ppm concentration. Criteria evaluated: number of roots, length of roots, and weight of roots.

\begin{tabular}{cccccc}
\hline Length & \multicolumn{3}{c}{ Weight } & Number \\
\hline Control & Latex & Control & Latex & Control & Latex \\
2.384091 & 2.2625 & 0,57 & 0,642 & 46 & 53 \\
1.581481 & 4.343902 & 0,180 & 1,326 & 27 & 41 \\
3.789189 & 2.053333 & 1,69 & 0,253 & 75 & 15 \\
4.342857 & 5.5 & 0,1518 & 0,253 & 7 & 16 \\
5.032258 & 1.557692 & 1,15 & 0,462 & 31 & 26 \\
2.887879 & 3.233333 & 0,5786 & 0,183 & 33 & 15 \\
3.434483 & 4.09375 & 0,734 & 0,236 & 58 & 16 \\
1.593333 & 2.572 & 0,19 & 0,252 & 16 & 25 \\
2.373913 & 6.088889 & 0,82 & 1,78 & 46 & 38 \\
2.444 & 3.714286 & 0,66 & 0,920 & 50 & 21 \\
$\mathbf{2 . 9 8 6 3 4 8}^{\mathbf{a}}$ & $\mathbf{3 . 5 4 1 9 6}^{\mathbf{a}}$ & $\mathbf{3 . 2 6 4 1 5 8 5}^{\mathbf{b}}$ & $\mathbf{3 . 2 6 4 1 5}^{\mathbf{b}}$ & $\mathbf{3 8 . 9}^{\mathbf{c}}$ & $\mathbf{2 6 . 6}^{\mathbf{c}}$ \\
\hline
\end{tabular}

a,b,c. In each variable evaluated, equal letters imply no significant difference in the results obtained.

Source: Authors.

\section{Discussion}

As already mentioned, in the present study the molluscicidal activity of E. milii latex was evaluated in the following dilutions: $2.5 \mathrm{ppm}, 1.25 \mathrm{ppm}, 0.625 \mathrm{ppm}$, and $0.3125 \mathrm{ppm}$, and it was observed that in all dilutions tested there was $100 \%$ mortality of adult mollusks of the species B. tenagophila.

The biological activity of E. milii latex observed agrees with results presented by several researchers, against several target species, including culicidae (Affeldt et al., 2016), terrestrial mollusks (Afonso-Neto, Bessa \& Soares, 2010), and aquatic mollusks (Vasconcellos \& Amorim, 2003; Coêlho et al., 2018; Martins et al., 2021).

Afonso-Neto, Bessa and Soares (2010) evaluated the molluscicidal activity of the latex of three species of Euphorbia against Leptinaria unilamellata D'Orbigny, a terrestrial gastropod mollusk, intermediate host of helminths pathogenic to birds and mammals, and observed that of the three species evaluated, namely, Euphorbia cotinifolia L., Euphorbia milii des Moul. var. splendens (Bojer ex Hook) Ursch and Leandri and Euphorbia tirucalli L., the only one with potential for use as a molluscicide was E. milii var splendens, which induced $100 \%$ mortality at the maximum dilution of $1250 \mathrm{ppm}(1.25 \mathrm{~g} / \mathrm{L})$.

The results presented are also in agreement with those obtained in other studies, in which the authors evaluated the molluscicidal activity of E. milii var splendens latex against aquatic mollusks of the Biomphalaria genus and demonstrated efficacy against the two most incriminated species as transmitters of Schistosoma mansoni, namely, B. glabrata (Coêlho et al., 2018) and B. tenagophila (Vasconcellos \& Amorim, 2003).

Coêlho et al. (2018) evaluated the molluscicidal activity of E. milii var splendens latex against B. glabrata and observed $100 \%$ mortality in all dilutions that were evaluated, including the lowest dilution tested in their experiments, namely $10 \mathrm{ppm}$. On the other hand, similarly to the experimental design of the present study, Vasconcellos and Amorim (2003) demonstrated the efficacy of the latex in question against the same target species, B. tenagophila, which induced $100 \%$ mortality of mollusks at the lowest dilution that these authors evaluated, namely, $5 \mathrm{mg} / \mathrm{L}$ (equivalent to $5 \mathrm{ppm}$ ), this concentration being significantly higher (16x) the minimum concentration capable of inducing $100 \%$ mortality of mollusks, which was observed in the present work, namely $0.3125 \mathrm{ppm}$.

The molluscicidal activity observed also agrees with the results presented by Oliveira-Filho and Paumgartten (2000). These researchers evaluated the biological activity of E. milii var splendens latex against B. tenagophila and A. salina, as well as several other target and non-target species, both to determine molluscicidal activity and to determine environmental toxicity, 
and showed that the toxic dilution $\left(\mathrm{LD}_{50}\right)$ of the latex of the plant species in question was in the order of 0.27 ppm for $B$. glabrata and $0.13 \mathrm{ppm}$ for B. tenagophila, with such values being very close to the results presented here $(0.3125 \mathrm{ppm})$ which, however, refer to a dose capable of inducing $100 \%$ mortality of B. tenagophila mollusks.

Concerning toxicity, in the test with A. серa, no change was observed in the parameters evaluated in relation to the control group, demonstrating a probable safety for use in the environment but in the test with A. salina, the latex of E. milii, at a dilution of $0.3125 \mathrm{ppm}$ induced mortality higher than that observed in the control group (56.6\% of mortality of nauplii in the treated group, against only $0.5 \%$ in the control group).

Although important mortality of A. salina was observed at the dilution of $0.3125 \mathrm{ppm}$, it is worth highlighting the possibility that in smaller dilutions, a persistence of the molluscicide activity can be observed, without however inducing mortality of non-target species. This hypothesis can be reinforced by the findings of Oliveira-Filho and Paumgartten (2000), according to which the toxic concentration for the target species in question, namely, B. tenagophila, was about 10 times lower than the toxic concentration for A. salina, thus increasing the potential for its use to control Biomphalaria populations in environmental reservoirs.

\section{Conclusion}

The results presented here allow us to conclude that the latex of E. milii var. splendens has high applicability for the control of B. tenagophila populations, highlighting the need to design future research for the isolation and identification of active principles and tests at larger scales, useful for planning new products with molluscicidal activity.

It is also important to highlight the need to design future tests with the latex in question, in dilutions less than 0.3125 ppm, to determine a $100 \%$ safe concentration, at which $100 \%$ mollusk mortality can be achieved and lower mortality of nontarget species.

\section{References}

Affeldt, P. E. S. et al. (2016). Avaliação da atividade inseticida de látex e extratos vegetais frente a culicídeos. Rev Biociências UNITAU, $22(1)$ : 61-67.

Afonso-Neto, I. S., Bessa, E. A \& Soares, G. L. G. (2010). Avaliação da atividade moluscicida do látex de três espécies de Euphorbia (Euphorbiaceae) sobre Leptinaria unilamellata D’Orbigny, 1835 (Gastropoda: Subulinidae). Rev Bras Plantas Med, 12: 90-95.

Brasil. (2014). Ministério da Saúde. Secretaria de Vigilância em Saúde Departamento de Vigilância das Doenças Transmissíveis. Vigilância da Esquistossomose Mansoni. Diretrizes técnicas (4a ed.).

Brasil. (2018). Secretaria de vigilância em saúde. Ministério da saúde. Situação epidemiológica e estratégias de prevenção, controle e eliminação das doenças tropicais negligenciadas no Brasil, 1995 a 2016. Boletim Epidemiológico, 49(49).

Coêlho, M. D. G. et al. (2018). Evaluation of toxicological and molluscicidal activities of lactiferous plants against Biomphalaria glabrata (Say, 1818). Sci Parasitol, 19(1-2): 1-6.

Everton, G. O. et al. (2020). Essential oils of the leaves of Syzygium cumini (L.) Skeels and fruit peels of Hymenaea courbaril (L.) var. courbaril as molluscides against Biomphalaria glabrata. Research, Society and Development, 9(10): e1239108215.

Fenwick, A. \& Jourdan, P. (2016). Schistosomiasis elimination by 2020 or 2030? International Journal for Parasitology, 46(7): $385-388$.

Gomes, P. R. B., Reis, J. B., da Silva, J. C., de Oliveira, R. W. S., de Paula, M. D. L., Louzeiro, H. C., \& Fontenele, M. A. (2019). Avaliação da toxicidade e atividade moluscicida do óleo essencial Cinnamomum zeylanicum Blume contra o caramujo Biomphalaria glabrata (Say, 1818). Revista Colombiana de Ciencias Químico-Farmacéuticas, 48(1), 122-127.

Holanda, E. C. et al. (2020). Epidemiological characterization and prevalence of schistosomiasis in State of Maranhão, Brazil. Research, Society and Development, 9(8): e735986622.

Lopes, T. A. et al. (2017). Distribution and identification of the genus Biomphalaria Preston (1910): Important insights into the epidemiology of Schistosomiasis in the Amazon region. Revista da Biologia, 17: 31-37.

Martins, T. G. T. et al. (2021). Molluscicidal activity in front of the Biomphalaria glabrata snail of the essential oil of Origanum vulgare L. Research, Society and Development, 10(10): e480101018964 
Research, Society and Development, v. 10, n. 12, e173101220189, 2021

(CC BY 4.0) | ISSN 2525-3409 | DOI: http://dx.doi.org/10.33448/rsd-v10i12.20189

Michelson, E. H. (1988). Application of biotechnology to the study of molluscan hosts of animal parasites. Southeast Asian J Trop Med Public Health, 19(1): 47-53.

Oliveira-Filho, E. C. \& Paumgartten, F. J. R. (2000). Toxicity of Euphorbia milii latex and niclosamide to snails and nontarget aquatic species. Ecotox Environ Safe, 46: 342-350

Pinto, T. S. Coêlho, M. D. G. Maciel, L. T. R \& Akisue, G. (2017). Avaliação da toxicidade de Euphorbia heterophylla L. Rev Ciên Saúde, 2 (2): 25-29.

Rocha, T. J. M. et al. (2016). Aspectos epidemiológicos e distribuição dos casos de infecção pelo Schistosoma mansoni em municípios do Estado de Alagoas, Brasil. Rev Pan-Amaz Saude, 7(2): 27-32.

Santos, I. G. A. et al. (2020). New epidemiological profile of schistosomiasis from an area of low prevalence in Brazil. Rev Soc Bras Med Trop, 53: e20200335.

Silveira, E. P. Marçal, O. J. \& Machado, M. I. (1997). Ocorrência de Biomphalaria straminea (Pulmonata: Planorbidae) na Estação de aqüicultura do IBAMA em Uberlândia, MG. Rev Soc Bras Med Trop, 30(5): 401-403.

Sociedade Brasileira de Medicina Tropical. Esquistossomose ainda é problema de saúde pública nas cidades. Publicação: 13 de fevereiro de 2013 https://www.sbmt.org.br/portal/noticias-774/.

Toor, J. et al. (2018). Are we on our way to achieving the 2020 goals for schistosomiasis morbidity control using current Health World Organization Guidelines. Clin Infect Dis, 66(4): S245-S252.

Vasconcellos, M. C. \& Amorim, A. (2003). Activity of Euphorbia splendens var. hislopii N.E.B. (Euphorbiaceae) latex against Lymnaea columella (Say, 1817) (Pulmonata: Lymnaeidae). intermediate host of Fasciola hepatica, Linnaeus, 1758 (Trematoda: Fasciolidae). 2: Limited Field-testing. Mem Inst Oswaldo Cruz, 98(7): 981-985. 